\title{
Wprowadzenie do arysto-tomizmu
}

\author{
Piotr Lenartowicz i Jolanta Koszteyn, Wprowadzenie do filozofii, \\ wyd. 4., Petrus, Kraków 2012, s. 184.
}

To w sumie szósta wersja omawianej pracy, pierwsza wyszła pod tytułem Wprowadzenie do zagadnień filozoficznych nakładem Kolegium Księży Jezuitów (1979); jednak wydania liczone są od publikacji przez Ignacjanum i WAM w roku 1998 (wyd. 1), 2000 (wyd. 2), 2004 (wyd. 3), 2011 (wyd 3. poprawione). Od 1998 roku z o. Lenartowiczem współpracowała Jolanta Koszteyn, udział w opracowywaniu kolejnych wersji brał też ks. Józef Bremer. Właściwa książka liczy niecałe 140 stron, bo prawie czterdzieści zajmuje słownik terminów. Nie wiedzieć czemu skorowidz został zatytułowany „Słownikiem osobowym i rzeczowym”. Poważną usterką jest brak bibliografii.

Zaznaczmy na wstępie, iż nie podoba nam się używany w pracy na oznaczenie filozofii arystotelesowsko-tomistycznej skrót AT (przypomina PGRy, PO i PZPRy), pozwolimy sobie zatem w ciągu dalszym na „,arysto-tomizm”. Książka jest $\mathrm{w}$ istocie częściowym wprowadzeniem do tej doktryny, odpowiadającym zainteresowaniom autorów, skupiającym się na ontologii i epistemologii. Stronniczość została zadeklarowana na samym wstępie i ostatecznie wychodzi książce raczej na korzyść, bo dzięki niej całość ma zdecydowanie afirmatywny charakter. Wyróżnia się przeto na tle zalegającej księgarnie parafilozoficznej makulatury, w której mnoży się pytania bez odpowiedzi.

Miejscami tej afirmatywności jest wręcz za mało, co okazuje się przede wszystkim przy okazji „metafizyki”. Nie mamy pretensji o to, że autorzy nie próbują rozwikłać całej plątaniny znaczeń tego terminu. Jednak ich własne okre- 
ślenie metafizyki, jako opisywanie świata „takim, jakim on w rzeczywistości jest" (s. 22), następuje mimochodem pod koniec mało zrozumiałych dla początkującego czytelnika wyrywkowych informacji o ewolucji znaczeń tego słowa. Co gorsza, synonimizacja metafizyki, teologiki i ontologii w ramach teorii bytu (s. 21) jest błędna, tak historycznie, jak i merytorycznie. Podobny problem występuje przy okazji wyróżnienia działów filozofii. Można było pominąc lub ograniczyć referowanie dawnych taksonomii, za to przedstawić jedną a prostą, choćby trójdzielną: ontologia, epistemologia, aksjologia. Ta ostatnia nigdzie w książce nie występuje, zaś autorska wersja „współczesnego” podziału filozofii niesie fałszywą sugestię, jakoby estetyka, etyka i filozofia kultury były zgoła oddzielnymi dziedzinami.

Tekst powstały w jednym obozie filozoficznym z konieczności kieruje się przeciwko całej reszcie. Ostentacyjna jest niechęć do Platona i do tych, których arysto-tomiści uważają za szkodliwą progeniturę intelektualną Ateńczyka: osobliwie do Kartezjusza i Kanta. Niestety animozje bywają łączone z niedopuszczalnymi uproszczeniami i fałszami, których niefilozof nie będzie w stanie wykryć. Taką symplifikacją jest przypisanie Sigerowi z Brabantu teorii dwóch prawd rozumianej jako dopuszczenie jednoczesnej prawdziwości pewnych par skądinąd wykluczających się tez, szczególnie, gdy jedna pochodzi z objawienia, a druga $z$ dyskursu naukowego (s. 34). Wittgensteina (s. 42-46) bałamutnie przedstawiono nie na podstawie tego, co sam był twierdził, tylko postronnych opinii, wtłaczając go w obcy mu schemat „filozofii językowej”. Fragment o Łukasiewiczu składa się wyłącznie z fantazji: rzekomo uznał on zasadę sprzeczności za konwencję językową (s. 116); spuśćmy zasłonę milczenia na zaklasyfikowanie go, tak jak Ayera i Nagela, jako reprezentanta „filozofii bezkrytycznej”. Autorzy nieco zbyt szybko prześlizgują się nad kłopotliwą dla arysto-tomistów i marksistów zbieżnością ich koncepcji epistemologicznych (s. 92).

$\mathrm{Z}$ drugiej strony autorzy kilkakrotnie deklarują chęć naprostowania nieporozumień wokół ich własnej doktryny. Autoprezentacja wydaje się rzeczowa, choć wykazuje zastanawiające luki. W części psychologicznej brak wyjaśnienia pojęcia woli, drugiej władzy intelektualnej duszy ludzkiej, odpowiedniego hasła nie ma też ani w słowniku terminów, ani w skorowidzu. 
Arysto-tomizm faktycznie przedstawiany bywa karykaturalnie, między innymi w aspekcie filozofii przyrody. Autorów interesuje głównie dział przyrody ożywionej, dokładają po pierwsze starań, by arystotelesowską koncepcję organizmów skontrastować z mechanicznym obrazem przyrody nieożywionej. Ośrodkową koncepcją jest w tym przypadku wewnętrzny dynamizm każdej istoty żywej, przejawiający się głównie w orientacji organizmu co do własnego środowiska wewnętrznego i zewnętrznego, co z kolei umożliwia działania manipulacyjne. Całej sekwencji dynamizmu przypisuje się jedną przyczynę, także immanentną a niematerialną, zwaną „formą substancjalną" lub „duszą”. Dusze organiczne układają się z kolei w znaną hierarchię, dusze zwierzęce określa się mianem ,osobniczych”, zaś ludzkie „osobowych”. Istotą sporu między arysto-tomistami a materialistami doby obecnej jest charakter różnicy między wewnętrznym dynamizmem organizmów zwierzęcych a ludzkich. Wedle tych pierwszych jest to nieprzekraczalna różnica jakościowa, wedle tych drugich jest to różnica ilościowa, przekraczalna na drodze ewolucyjnej.

Na zakończenie zauważmy, że niestarannie wykonano korektę: powinno być np. „egzystencjalizmie”, zamiast „egzystencjaliźmie” (s. 67), analogicznie „nominalizmie”, nie „nominaliźmie” (s. 52), „Sekstus Empiryk”, nie „Sextus Empiricus" (s. 120 i dalej: zniekształcony odnośnik do thumaczenia Krokiewicza Zarysów pirrońskich).

Oczekujemy na kolejną, ulepszoną edycję tej niewątpliwie potrzebnej książki. Omówione niniejszym wydanie pojawiło się niedługo przed śmiercią o. Lenartowicza, który odszedł w październiku 2012 roku. Częściej żeśmy się spierali, niźli zgadzali, lecz bardzo nam Go brakuje. 